\title{
The Reproductive Maturity of the Common Eel.
}

\author{
By
}

\section{J. T. Cunningham, M.A.}

In the Museum of the Royal College of Surgeons, in London, there are two specimens of the common eel, in which the ovaries are much enlarged, greatly distending the abdomen, and evidently very nearly ripe. Both those specimens were presented by Mr. Geo. Buckeridge, a salesman in Billingsgate Market, who deals largely in eels. The following are certain particulars concerning the specimens :-

(1) Length 15 in., weight $4 \frac{1}{2}$ oz. Presented Jan. 4, 1894.

(2) Length $19 \mathrm{in}$., girth round the abdomen $5 \frac{1}{2}$ in., weight $10 \frac{1}{4} \mathrm{oz}$. Presented Sept. 25, 1895.

Both specimens are in spirit, mounted for exhibition, and the ovaries are seen to be of opaque milk-white colour, and generally to present the same appearance as the nearly-ripe ovaries of the Conger described by me in Vol. II. of this Journal. The greatest width of the ovaries is $1 \frac{7}{8}$ in. or $4.8 \mathrm{~cm}$. The eggs are scarcely visible as distinct grains to the naked eye. Microscopically examined in a small piece which Professor Stewart kindly gave me from the larger specimen, the largest eggs were found to be from 13 to $16 \mathrm{~mm}$. in diameter, while the smallest were only $.07 \mathrm{~mm}$. It is a remarkable fact that eggs considerably larger than this have been found in the unripe ovaries of eels in the ordinary condition. Mr. Williamson (Thirteenth Annual Rep. of Scottish Fishery Board, 1895) states that in a specimen $70.7 \mathrm{~cm}$. long ( $28 \frac{1}{3}$ in.), some of the eggs measured $\cdot 27 \mathrm{~mm}$., and several other observers have given the maximum size as $25 \mathrm{~mm}$. In the ripe specimen described by Rathke, in 1850, the eggs were also small, not exceeding $.2 \mathrm{~mm}$. In the specimen here under description, the microscope showed that the ovarian lamellae were composed almost entirely of ova in close apposition, the adipose tissue so plentiful in the ordinary condition of the ovary having been absorbed. It should be remembered that the eggs were measured after preservation in spirit, which must have caused contraction; but Rathke, who examined his specimen when it was fresh, also remarks that the eggs were distinctly smaller than in eels with small ovaries. 
Fig. 1 represents accurately the appearance of the second specimen when mounted, the abdomen having been opened in the mid-ventral line. The figure is printed from a block prepared for the Field, and lent to me by the kindness of W. B. Tegetmeier, Esq.

The time of year at which these specimens were obtained agrees with the conclusion drawn from other evidence, that eels spawn in autumn or winter, and serves to determine the actual fact that some eels are on the point of spawning at the end of September and beginning of January. The equally important question of the place of their capture has next to be considered. Mr. Buckeridge, who very kindly answered the enquiries I made to him on the matter, told me that both specimens were found among consignments of eels from Toom Bridge, in Ireland. Now Toom Bridge is at the point where the river Bann leaves Lough Neagh, and is about 26 geographical miles from the sea. It is certainly an extraordinary fact that an eel so near the ripe condition should be found in fresh-water. We can only suppose that the case is exceptional. There is a possibility that the specimen had been kept in captivity for some time after being caught, and that thus its ovaries had had time to develop. But, on the other hand, when eels have been kept in saltwater aquaria, as they have been at the Plymouth Laboratory, in order that ripe specimens might be obtained, the ovaries have not developed to any obvious degree.

Rathke's specimen is described in Müller's Archiv. für Anat. Physiol. \&c. 1850. It was brought to him, presumably in Berlin, by a fisherman on May 24th. It was dead, but in fresh condition. Nothing is stated concerning its place of capture. The ovary was $1 \frac{1}{2}$ in. wide in its middle part. The fat, which in ordinary eels is abundant between the eggs, was almost entirely absent. The importance of the condition of this specimen to Rathke's mind was the evidence it supplied that the eel was oviparous, and not viviparous.

It would appear that in addition to Rathke's specimen and the two here described, only one other nearly ripe female eel has been recorded. This fourth specimen is that mentioned by Calderwood, in a note in the Ann. and Mag. Nat. Hist. (6), vol. xii. 1893. But the description given is very scanty. The specimen was $29 \frac{1}{2}$ in. long, and was captured on December 27, 12 miles south of the Eddystone Lighthouse, or 20 miles from Rame Head, the nearest point of land. The width of the ovary and the size of the eggs are not mentioned. All that is stated is that the ovaries corresponded exactly in appearance with those figured and described by Brock in 1881, but Brock did not mention a ripe specimen. The ova are said to have been apparently ready to drop from the surface of the ovary, and to have been richly stored with oil globules. 


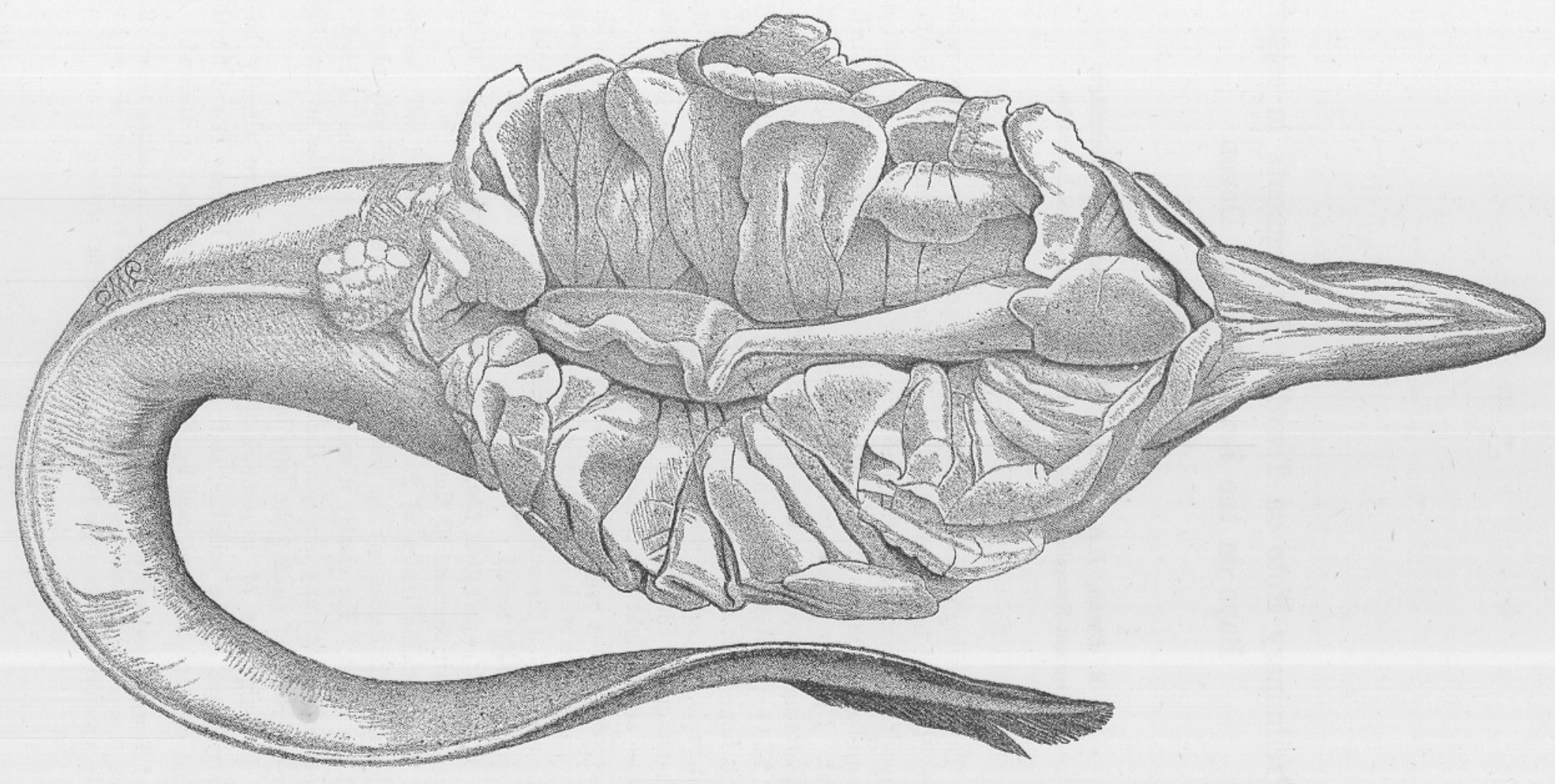

Fio. 1,-Female eel, with ovaries much enlarged and nearly ripe. (From specimen in the Royal College of Surgeons' Museum.) 